\title{
Proceeding
}

Supplementary Issue: Winter Conferences of Sports Science. Costa Blanca Sports Science Events, 25-26 January 2019.

Alicante, Spain

\section{Biodanza laboratory and experimental pedagogy}

\author{
ROBERTA ROSA, ANTONIO ASCIONE $\checkmark$, DAVIDE DI PALMA \\ Department of Motor and Well-being Sciences, University Parthenope of Naples, Italy
}

\begin{abstract}
This contribution aims to investigate whether the Biodanza SRT tool can be an experimental pedagogical approach able to positively stimulate the development of self-esteem, self-confidence, self-efficacy and the promotion of learning and motivation also in school systems. It is an important component to be correlated in the main training processes of the individual. In this regard, for a sample of school-age subjects, a Biodanza laboratory activity was proposed (divided into seven meetings) and, at the end of the same, through a mixedtype questionnaire, the pedagogical effectiveness of this project was assessed. Key words: Biodanza SRT; Experimental pedagogy; School systems; Formative processes; Laboratory activity.
\end{abstract}

\section{Cite this article as:}

Rosa, R., Ascione, A., \& Di Palma, D. (2019). Biodanza laboratory and experimental pedagogy. Journal of Human Sport and Exercise, 14(2proc), S169-S177.

doi:https://doi.org/10.14198//hse.2019.14.Proc2.03

Corresponding author. Department of Motor and Well-being Sciences, University Parthenope of Naples, Naples, Italy.

E-mail: antonio.ascione@uniparthenope.it

Supplementary Issue: Winter Conferences of Sports Science. Costa Blanca Sports Science Events, 25-26 January 2019. Alicante, Spain.

JOURNAL OF HUMAN SPORT \& EXERCISE ISSN 1988-5202

(C) Faculty of Education. University of Alicante.

doi:10.14198/jhse.2019.14.Proc2.03 


\section{INTRODUCTION}

Biodanza SRT is an inclusive teaching-learning strategy that, through the promotion of personal well-being, contributes to the achievement of a Physical Literacy: an essential human capability that includes motor, emotional, relational and cognitive skills (life skills) useful for consolidating the awareness of the value and importance of a constant practice of motor and sport activities throughout life. Physical literacy means the literacy of the body developed throughout life, which affects not only the emotional, social, cognitive and motor areas, but it also includes maintaining the ability to interact with different environments through the senses, perceive and better manage, with control and moderation, one's own body in movement (Whitehead, 2010). Physical Literacy is expressed through choices, attitudes and behaviours oriented towards an active lifestyle, corresponding to a set of skills and competences (life skills) that guarantee the improvement of physical, psychological, cognitive, affective and social well-being (Whitehead, 2010); moreover, it is an excellent key to gaining good practices aimed at a healthy lifestyle from birth, and maintaining them to the old age (Whitehead, 2010, 2013). Physical Literacy (PL) can be described as motivation, trust, physical competence, knowledge and comprehension to evaluate and take responsibility for the commitment to physical activities for life. Considering the body the place of emotional life and where Biodanza SRT relationships develop facilitates greater integration between mind and body emotions, in order to get a person's complete development through an active learning method. Through the "Learning-by-doing" approach, Biodanza SRT offers the opportunity to learn and experience life through a fascinating journey to discover one's own healthy side, in order to stimulate the process of personal renewal, positive selfassessment, self-esteem, and social integration by respecting human community and life.

In this regard, the training potential of an experimental proposal for students, focused on a Biodanza laboratory within the school context, will be evaluated with specific reference to motor and sports education.

\section{Biodanza as a Pedagogical Experience}

Biodanza SRT is configured as body-mediated Holistic Social Pedagogy based on a Biocentric Education (life at the centre), and finds its foundations in life sciences (biology, physiology, psychology, education, anthropology, sociology, neuroscience, human sciences, epigenetics). It is a system of Human Integration, organic renewal, affective education and learning of the original life functions, representing a valid contribution to the full and integral formation of personal identity and to the person's harmonious and full development. Through corporeity and the stimulation of emotional intelligence, it fosters the integration between learning and cognitive knowledge, facilitating the affective education, the person's overall and harmonious development (Toro Araneda, 2012), the Existential Rehabilitation (bio-psycho-social) and the Personal Empowerment. This system of personal growth and human evolution awakens attention to oneself, the others and the context, to sensitivity and empathy, so as to gradually increase self-confidence, selfesteem, self-efficacy, the ability to listen and strengthen Identity by improving well-being and the quality of personal and social life (Rosa, De Vita 2018). The SRT Biodanza System is based on the Biocentric Principle (life put at the centre), and through Biocentric education, it intends to favour the integration between learning and cognitive knowledge through the languages of the body and emotions, in order to facilitate an affective education and a person's global and harmonious development (Toro Araneda, 2012). In this pedagogical approach, the group function is an essential element to realize the personal and social growth process for it induces new forms of communication and emotional bonding. The group is a matrix of rebirth in which each participant finds the affective control that grants him a change. The presence of the "similar" changes the person's functioning at all his levels, both organic and existential. 
In Biodanza SRT, the "group" is the irreplaceable relational field of people's process of growth and change, and is a tool for strengthening identity and the sense of belonging to a common feeling by acting on various functions:

- Permissive function: right to reduce the defence mechanisms power; right to be, to express oneself, to explore and risk, and to overturn the rules.

- Facilitating function: strengthening everyone's healthy expressions, stimulating the vital momentum, the desire for contact, joy, creativity, and potentialities.

- Deflagrating function: making "the growth process haste", speeding it up, bringing out aspects of the self that were in the shade, and favouring insights.

- Integrating function: putting together parts of oneself, relating, moving, accepting different parts, finding creative ways to make them live together, not denying parts, bringing them to light and taking care of them.

- Creative function: inducing expressive situations.

- Transcendent function: fostering the experience of a whole and its parts in movement, going beyond the ego, exploring the undifferentiated with the possibility of perceiving the essence of people, beyond prejudice and social labels, living a sense of belonging as opposed to isolation.

During the Biodanza SRT session, a real "empathetic network " is built, which constitutes in all respects an group inter-subjective space within which there is a continuous exchange of experiences, an emotional resonance and a mutual recognition allowing the participants being reflected in each other, recognizing themselves, discovering one another reciprocally, strengthening one's own identity and restoring awareness of one's own transformation and change process (Tafuri et al, 2019; Toro Acuna, Demelas, 2013). Realizing "one's own dance" does not mean emulating a movement to perfection or learning pre-established movement codes; it means integrating one's own feelings with one's own actions, creating a communion between feelings and emotions that animate us and the visible expression of our way to move into the world.

The Biodanza SRT Training is designed to induce people to fully and creatively live their own lives by establishing "functional" intra-personal and inter-personal relationships, favouring the indispensable prerequisites for personal and collective growth and development (Rogers, 2007). Through a person-centred approach in a facilitating and non-judgmental atmosphere (by respecting and paying attention to oneself and to the other) it stimulates an optimistic attitude (positive vision), self-efficacy (confidence in one's own abilities), self-esteem, empathy, emotional management, and empowerment (development of potentialities). By acquiring a "personal power", the subject gains greater self-confidence, develops his abilities and talents to the fullest, becoming the protagonist of his own growth and contributing to realizing of his own pedagogical development (Stueck, 2008; 2010; 2011; Witruk, Reschke and Stueck, 2009).

\section{The Potential of a Biodanza Laboratory in Educational Contexts}

Biodanza SRT, as a path of Pedagogical and Didactic Coaching, carries out an action that involves the Psycho-Motor-Affective-Relational aspects, potentially resulting in a valid educational intervention to be integrated into the training programs, also at school level.

Biodanza SRT is a system of an extraordinary methodological innovation, which manages to move from the cultural dimension by offering an opportunity for professionals to rethink the educational process not only as a right to education, but above all, as an experience capable of guiding the individual (and then the student) in a path that stimulates autonomy and independence. It is a method that induces to use corporeity to work on oneself by reliving sensations and emotions through a dance-movement process, which, once elaborated 
at unconscious level, generate new learning, awareness and knowledge to be employed even in everyday life.

This methodology encompasses various activities: dance, music, interpretation, vivencial theatre, writing, drawing, sculpture, painting, which therapeutically stimulate individual creativity, the sense of belonging to a group and new relational dynamics, by encouraging the strengthening of identity, personal self-esteem and self-efficacy, and by actively contributing to a new approach to life. It could potentially set itself as an experimental and innovative didactic methodology aiming at the promotion of learning as a way to "feel good", with the aim of strengthening motivation and empowerment in people.

Through a workshop proposal focused on Biodanza, employed also in a school system, in addition to developing the skills embedded in the disciplines based on corporeity (in a perspective of pedagogical and didactic training), those that Bandura (1997) frames as the five mechanisms, making the individual capable of planning the course of his actions and aiming at reaching certain goals, are developed too; these are: symbolization, anticipation, vicarious learning, self-reflection and self-regulation.

- Symbolization is the ability to turn the experience into verbal and imaginative symbols, allowing living the experiences into internal models, which offer the possibility of finding appropriate solutions to different situations and plan future actions.

- Anticipation is the ability to cognitively elaborate and anticipate the consequences of one's own actions. It acts on everyone's motivation to act, and allows us balancing the resources and efforts required.

- Vicarious experience is a fundamental possibility for human development, since it allows learning through the observation of behaviours implemented by others and their consequences. This ability favours the "modelling" experience, through which the most effective behaviours are selected and chosen.

- Self-reflection is a strategy of one's own thoughts evaluation, and of one's own decisions and actions quality elaboration. It makes use of the reflection on experience, observation, anticipation of results, allowing the person gaining self-confidence (Bandura, 1994, 1997).

- Self-regulation plays a key role in the processes regulating the choice of objectives and the related strategies: through self-monitoring, self-assessment and self-management, the person is able to supervise his own choices, solutions and objectives.

Furthermore, this activity allows assimilating and shaping four types of "experiences", important in the individual's effective growth: the experience of mastery, vicarious experience, persuasion, emotional and physiological states.

- The experience of mastery (or direct experience) strengthens the sense of personal effectiveness as the objectives achieved allow experimenting with one's own resources and abilities. The experience of challenging successes strengthens the person, thanks to which he can be more or less determined. On the contrary, if only experiencing easy successes, people will tend to expect quick results and may then become discouraged by higher obstacles to overcome.

- Vicarious experience, or social modelling, is a process of observation and comparison with other people who have pursued the same objectives. From this, the identification allows increasing one's own efforts and having more confidence in one's own chances of success: people seek models to refer to, suitable and steady in their experience (Bandura, 1994; Schunk, 1987). 
- Verbal persuasion helps corroborate self-efficacy if it is supported by action, and if the person recognizes and trusts in "persuaders" by attaching them credibility and relevance.

- Being in touch with one's own sensations, and being aware of one's own emotional and physiological states helps reduce vulnerability to stress. Listening to one's own body and having a good contact with oneself allow monitoring one's own reactions to unexpected events, and recognizing hard situations by producing a virtuous circuit that positively affects the health and quality of everyday life.

\section{Biodanza Laboratory in the School System: an Experimental Proposal}

The experimental proposal includes the inclusion of a Biodanza Laboratory in the Motor and Sports Education didactic proposal of a second grade education school, in order to evaluate its contribution in learning. The aim is to analyse whether the pedagogical values encompassed in the Biodanza methodological proposal are such as to contribute to the student's training development in the physical and sports sciences field, and therefore if this proposal can represent a potential component to be included in the school system.

\section{METHOD}

It is essential to state that the experimentation was based on the collaboration and skills of the motor and sports education teacher of the "sample" class, which was the object of the project.

Didactic Discipline in which the Laboratory on Corporeity was included: Motor and Sports Education. Experimental Methodology: Biodanza Laboratory.

The sample consisted of 16 third school year students of a second grade education institution: 12 males (M) - 4 females $(F)$ - average age: 16.4 years. A subdivision into 2 homogeneous groups was carried out by gender and starting level: Experimental Group: 6 M - 2 F; Sample group: 6 M - 2 F.

Duration: 10 weeks - 2 weekly lessons of 1 hour each - For a total of 20 lessons (20 hours).

Maximum number of hours of absence for the student to be considered valid element in the experimentation: 3 hours.

The Experimental Group included the Biodanza Laboratory in its didactic program for a $50 \%$ of the lessons, while the Sample Group carried out the traditional Motor and Sports Education program.

The Evaluation Protocol employed, structured in collaboration with the teacher who also had previous knowledge of the entire sample, is summarized in the following diagrams; it is contextualized to the grade and school year of the class employed as research sample, and is composed of the scheme of evaluation indicators and descriptors and the related docimological scale. The students underwent a "pre" and a "post" design phase evaluation. 
Table 1. Indicators and Descriptors of the Evaluation

\begin{tabular}{|c|c|c|}
\hline INDICATORS & \multicolumn{2}{|c|}{ DESCRIPTORS } \\
\hline $\begin{array}{l}\text { Awareness of } \\
\text { one's own body. }\end{array}$ & $\begin{array}{l}\text { - Inadequate } \\
\text { - Partial } \\
\text { - Adequate }\end{array}$ & $\begin{array}{l}\text { - Complete } \\
\text { - Certain }\end{array}$ \\
\hline $\begin{array}{l}\text { Ability to communicate } \\
\text { through the body }\end{array}$ & $\begin{array}{l}\text { - Mediocre } \\
\text { - Sufficient } \\
\text { - Good }\end{array}$ & $\begin{array}{l}\text { - Fair } \\
\text { - Very good / } \\
\text { Excellent }\end{array}$ \\
\hline $\begin{array}{l}\text { Mastery of the } \\
\text { motor and postural schemes }\end{array}$ & $\begin{array}{l}\text { - Poor } \\
\text { - Sufficient } \\
\text { - Acceptable }\end{array}$ & $\begin{array}{l}\text { - Adequate } \\
\text { - Certain and } \\
\text { complete }\end{array}$ \\
\hline $\begin{array}{l}\text { - Ability to orientate oneself } \\
\text { within the known and unknown space }\end{array}$ & $\begin{array}{l}\text { - Poor } \\
\text { - Partial } \\
\text { - Adequate }\end{array}$ & $\begin{array}{l}\text { - Certain } \\
\text {. Complete and } \\
\text { immediate }\end{array}$ \\
\hline $\begin{array}{l}\text { Knowledge and respect } \\
\text { for the rules in game-sports activities }\end{array}$ & $\begin{array}{l}\text { - Unacceptable } \\
\text { - Poor } \\
\text { - } \\
\text { Discontinuous }\end{array}$ & $\begin{array}{l}\text { - Constant and correct } \\
\text { - Conscious and } \\
\text { correct }\end{array}$ \\
\hline $\begin{array}{l}\text { Knowledge of the essential concepts related to psycho- } \\
\text { physical well-being }\end{array}$ & $\begin{array}{l}\text { - Poor } \\
\text { - Inadequate } \\
\text { - Acceptable }\end{array}$ & $\begin{array}{l}\text { - Relevant } \\
\text { - Certain and } \\
\text { complete }\end{array}$ \\
\hline
\end{tabular}

Source: Our Elaboration.

Table 2. Docimological Scale

\begin{tabular}{|c|c|}
\hline SCORE & EVALUATION CHARACTERISTICS ASSOCIATED WITH THE SCORE \\
\hline$<5$ & $\begin{array}{l}\text { - Scarce or non-evaluable skills } \\
\text { - Rejection of commitment }\end{array}$ \\
\hline 5 & $\begin{array}{l}\text { - Inadequate awareness of one's own body } \\
\text { - Mediocre ability to communicate through the body } \\
\text { - Poor mastery of the motor and postural schemes } \\
\text { - Poor ability to orientate oneself within the known and unknown space } \\
\text { - Unacceptable knowledge and respect of the rules in game-sports activities } \\
\text { - Poor knowledge of the essential notions related to psycho-physical well-being }\end{array}$ \\
\hline 6 & $\begin{array}{l}\text { - Partial awareness of one's own body } \\
\text { - Sufficient ability to communicate through the body } \\
\text { - Sufficient mastery of one's own motor and postural schemes } \\
\text { - Partial ability to orientate oneself within the known and unknown space } \\
\text { - Poor knowledge and respect of the rules in game-sports activities } \\
\text { - Inadequate knowledge of the essential notions related to psycho-physical well-being }\end{array}$ \\
\hline 7 & $\begin{array}{l}\text { - Adequate awareness of one's own body } \\
\text { - Acceptable ability to communicate through the body } \\
\text { - Good mastery of one's own motor and postural schemes } \\
\text { - Adequate ability to orientate oneself within the known and unknown space } \\
\text { - Good knowledge but discontinuous compliance with the rules in game-sports activities } \\
\text { - Acceptable knowledge of the essential notions related to psycho-physical well-being }\end{array}$ \\
\hline 4 & 2019 | Proc2 | VOLUME 14 \\
\hline
\end{tabular}




\begin{tabular}{|c|c|}
\hline 8 & $\begin{array}{l}\text { - Complete awareness of one's own body } \\
\text { - Fair ability to communicate through the body } \\
\text { - Adequate mastery of one's own motor and postural schemes } \\
\text { - Certain ability to orientate oneself within the known and unknown space } \\
\text { - Constant and correct knowledge of the compliance with the rules in game-sports activities } \\
\text { - Relevant knowledge of the essential notions related to psycho-physical well-being }\end{array}$ \\
\hline 9 & $\begin{array}{l}\text { - Certain awareness of one's own body } \\
\text { - Excellent ability to communicate through the body } \\
\text { - Certain mastery of one's own motor and postural schemes } \\
\text { - Thorough ability to orientate oneself within the known and unknown space } \\
\text { - Conscious knowledge and respect of the rules in game-sports activities } \\
\text { - Certain knowledge of the essential notions related to psycho-physical well-being }\end{array}$ \\
\hline 10 & $\begin{array}{l}\text { - Certain awareness of one's own body } \\
\text { - Excellent ability to communicate through the body } \\
\text { - Certain and thorough mastery of one's own motor and postural schemes } \\
\text { - Thorough and prompt ability to orientate oneself within the known and unknown space } \\
\text { - Conscious and correct knowledge of the compliance with the rules in game-sports activities } \\
\text { - Certain and thorough knowledge of the essential notions related to psycho-physical well-being }\end{array}$ \\
\hline
\end{tabular}
Source: Our Elaboration.

\section{Results and Observations}

First of all, it should be noted that no student exceeded the 3-hour absence limit (with a resulting drop-out rate of 0 ). Below is the table with the outcomes of the Evaluation Test, which indicate the number of students who have chosen every single possible answer. To code the students, the prefix "E" was employed for the experimental group, and the prefix "C" for the control group; the boys were randomly numbered from 1 to 8 and the letter "M" was employed for males and " $F$ for females.

Table 3. Evaluation Test Outcomes

\begin{tabular}{|c|c|c|c|c|c|c|c|}
\hline $\begin{array}{c}\text { Group } \\
\text { control } \\
\text { students }\end{array}$ & $\begin{array}{c}\text { Pre- } \\
\text { evaluation }\end{array}$ & $\begin{array}{c}\text { Post } \\
\text { evaluation }\end{array}$ & Difference & $\begin{array}{c}\text { Experimental } \\
\text { group } \\
\text { students }\end{array}$ & $\begin{array}{c}\text { Pre- } \\
\text { evaluation }\end{array}$ & $\begin{array}{c}\text { Post } \\
\text { evaluation }\end{array}$ & Difference \\
\hline C1M & 6 & 6 & 0 & E1M & 5 & 6 & +1 \\
\hline C2M & 7 & 7 & 0 & E2M & 8 & 8 & 0 \\
\hline C3M & 6 & 7 & +1 & E3M & 6 & 7 & +1 \\
\hline C4M & 7 & 7 & 0 & E4M & 7 & 7 & 0 \\
\hline C5M & 7 & 8 & +1 & E5M & 7 & 7 & 0 \\
\hline C6M & 8 & 8 & 0 & E6M & 6 & 7 & +1 \\
\hline C7F & 6 & 6 & 0 & E7F & 6 & 7 & +1 \\
\hline C8F & 5 & 6 & +1 & E8F & 7 & 8 & +1 \\
\hline
\end{tabular}

Source: Our Elaboration.

In the overall, in terms of scores, the training level of the two groups was homogeneous and this allowed us observing which of the two didactic protocols allowed for a more effective training development in motor and sports education. In neither of the two groups the students showed reduced level of training, nor a positive difference in the assessment exceeding 1 score was observed. More specifically, in the control group, 3 
students achieved an improvement (37.5\%), while in the experimental group, a training growth was observed in 5 students (62.5\%). This data provides a very important indication of the effectiveness of an experimental proposal in Motor and Sports Education, combining the traditional didactic proposals also with the Biodanza laboratory understood in its pedagogical perspective. It is also important to specify that what we evaluated does not yet allow us claiming with certainty the validity of this project, due to certain factors such as the homogeneity and reduced sample size, and the limited duration of the experimentation phase. In any case, the presence of a didactic and pedagogical potential that should arouse considerable interest in the research activity in this field remains true, and deserves further investigations of scientific importance.

\section{CONCLUSIONS}

The theoretical and practical approach expressed by the discipline of Biodanza SRT has gained, over time, an increasingly convincing value in the pedagogical field and, at this point, its adoption also in the school context can be assumed, in order to increase the effectiveness of the didactic proposal for the student's full training development. The experimental part of this work confirmed the presence of this potential to be exploited within the school discipline of Motor and Sports Education. This work is the basis for future research ideas, which could consider the increase in the sample size and its differentiation both in terms of education and type and address of the school context; moreover, the willingness to evaluate the way this laboratory could be included even within disciplines not directly related to corporeity, in order to ascertain the effectiveness of this experimental proposal for the whole didactic structure of the school context, could also arouse the interest of the Pedagogical Community.

\section{CONTRIBUTIONS}

The manuscript is the result of a collective work of the authors, the specific contribution of which is to be referred to as follows: the introduction and paragraph $n$. 2 are to be attributed to Roberta Rosa, paragraph n.1 and the Conclusions to Antonio Ascione, paragraph n.3 to Davide Di Palma.

\section{REFERENCES}

Bandura, A. (1994). Regulative function of perceived self-efficacy. In M. Rumsey, C. Walker, \& J. H. Harris (Eds.), Personal selection and classification (pp. 261-271). Hillsdale, NJ: Erlbaum.

Bandura, A. (1997), Self-efficacy: The exercise of control, New York, Freeman; It. Transl. Autoefficacia, Trento, Erickson.

Rogers C. (2007). La relazione efficace nella psicoterapia e nel lavoro educativo. Carocci Editor, Roma.

Rosa R., De Vita T, (2018). The educational value of Corporeality and Motor Activities in learning of Life Skills Education in School. Sport ... as Educational Tool, Italian Journal of Health Education, Sports and Inclusive Didactics, , Anno 2 n.1 a cura di F. Peluso Cassese, Edizioni Universitarie Romane. Roma.

Schunk, D. H. (1987). Peer models and children's behavioral change. Review of Educational Research, 57, 149-174. https://doi.org/10.3102/00346543057002149

Stueck, M. (2008) New ways: Yoga and Biodanza in the stressreduction for teachers. Strasburg: Schibri Publishing House.

Stueck, M. (2010). Children, researchers, educators - Early education on the Test (Masterplan healthy education under use of BIODANZA). In M. Stueck (Ed.), Contributions to healthy education. Strasburg: Schibri Publishing House. 
Tafuri, D., Rosa, R., Di Palma, D., \& Ascione, A. (2019). An innovative Educational-Sport strategy to aim to inclusion: Biodanza SRT. Journal of Human Sport and Exercise, 14(1proc), S1-S10. https://doi.org/10.14198/ihse.2019.14.Proc1.01

Toro Acuna, G.C., Demelas, L. (2013). IBF - International Biocentric Foundation - Rete CIMEB Rete Mondiale dei Centri di Investigazione delle Musiche e degli Esercizi di Biodanza® "Biodanza e Neuroscienze" Dispensa Formazione Insegnanti Biodanza Sistema Rolando Toro, Editorial Eleusis.

Toro Araneda, R. (2007) Biodanza: musica, movimento, comunicazione espressiva per lo sviluppo armonico della personalità, Editions Red, Como.

Toro Araneda, R. (2012). Teoria della Biodanza, raccolta dei testi a cura della A.L.A.B. (Associazione Latino-Americana di Biodanza), CIMEB testi, Volume I, Editions Nuova Prhomos, Perugia.

Whitehead, M. (2010). Alfabetizzazione fisica durante il corso di vita . Londra e NewYork: Routledge. pp. 12-14 Physical Literacy. Throughout the lifecourse. New York, NY: Routledge.

Whitehead, M. (2013). The value of physical literacy. Journal of Sport Science and Physical Education, 65.

Witruk, E., Reschke, K. \& Stueck M. (2009). Psychological stress of emergency workers - and psychological effects of emergency aid for victims of the tsunami disaster in Sri Lanka and Indonesia. In trauma and violence (under use of BIODANZA). In Trauma und Gewalt. Klett-Cotta.

\section{(2) $\odot \Theta \Theta$}

This work is licensed under a Attribution-NonCommercial-NoDerivatives 4.0 International (CC BY-NC-ND 4.0). 